\title{
Anti-Müllerian hormone (AMH) as a predictor of antral follicle population in heifers
}

\author{
Christopher Júnior Tavares Cardoso ${ }^{1}$, Jair Sábio de Oliveira Junior ${ }^{2}$, Henrique Kischel ${ }^{3}$, Wilian Aparecido \\ Leite da Silva ${ }^{3}$, Elielton Dias da Silva Arruda ${ }^{3}$, Mirela Brochado Souza-Cáceres ${ }^{4}$, Fernanda Amarante \\ Mendes de Oliveira ${ }^{5}$, Ériklis Nogueira ${ }^{6}$, Guilherme de Paula Nogueira ${ }^{7}$, Fabiana de Andrade Melo-Sterza ${ }^{1,3,8}$ \\ ${ }^{1}$ Federal University of Mato Grosso do Sul, Campo Grande, MS, Brazil. \\ ${ }^{2}$ Veterinary Medicine, Biomedical Sciences Faculty of Cacoal, Cacoal, RO, Brazil. \\ ${ }^{3}$ Laboratory of Animal Reproduction Biotechnologies, State University of Mato Grosso do Sul, Aquidauana, MS, Brazil. \\ ${ }^{4}$ State University of Londrina, Londrina, PR, Brazil. \\ ${ }^{5}$ Federal Institute of Education, Science and Technology of Amazonas, Tabatinga, AM, Brazil. \\ ${ }^{6}$ Embrapa Pantanal, Corumbá, MS, Brazil. \\ ${ }^{7}$ State University of São Paulo, Araçatuba, SP, Brazil.
}

\begin{abstract}
Antral follicular population (AFP) and antiMüllerian hormone (AMH) concentration are strongly associated. Thus, analyzing $\mathrm{AMH}$ concentration is a reliable method to predict animals with high AFP, an important feature to select donor cows for embryos and oocytes. However, not much is known about this parameter in heifers, particularly in crossbred animals. The aim of this study was to assess AFP in heifers and cows and its relation to serum AMH levels. Bos taurus indicus cows (36-60-months-old; $\mathrm{n}=30$ ) and heifers (12-14-months-old; $n=17$ ) of the same breed were evaluated. A single procedure of follicular counting was performed by ultrasound for each animal. Random sampling was performed to analyze serum AMH concentration. Cows showed higher AFP than heifers; nonetheless, plasma AMH concentration did not differ between the categories. A high correlation of AFP with plasma AMH concentration was observed in Girolando heifers. Thus, it is suggested that AMH concentration could be a reliable and less invasive method for selecting heifers with high AFP.
\end{abstract}

Keywords: bovine, follicles, selection donors.

\section{Introduction}

Taking advantage of the rusticity of the Gir breed and the dairy productivity of the Holstein breed, Girolando cows are currently the main breed for milk production in Brazil, comprising around $80 \%$ of the dairy cattle in the country (Borges et al., 2012). To improve dairy production, selection of females with high productivity, better reproductive efficiency, and/or better competence to respond to reproduction biotechnologies is essential.

The first calving age is approximately 35 months for $3 / 4$ Holstein $\times 1 / 4$ Gir cows, (Silva et al., 2014), however a high variability among herds (lineages) has been observed. Taking that into account, strategies are needed to reduce the age for first calving and to select animals with higher genetic potential to attain the desired traits.

Phenotypic traits linked to infertility are associated with low ovarian antral follicle population
(AFP) in B. taurus (Ireland et al., 2011). Nevertheless, the relationship between AFP and fertility has not been observed in B. indicus (Nellore) and crossbred beef cows (Baruselli et al., 2015; Morotti et al., 2015; SilvaSantos et al., 2014a). The number of recruited follicles in each follicular wave is highly variable between individuals; however, a high level of individual repeatability is observed (Evans et al., 2010; Oliveira Junior et al., 2015; Batista et al., 2014; Gobikrushanth et al., 2017). High correlation of AFP with in vivo and in vitro embryo production may be used as an auxiliary tool to select donor cows for embryos and oocytes (Silva-Santos et al., 2014a; Baruselli et al., 2015; Ghanem et al., 2016).

AFP is positively correlated with anti-Müllerian hormone (AMH) (Baldrighi et al., 2014; Guerreiro et al., 2014). The glycoprotein AMH, which belongs to the transforming growth factor (TGF)- $ß$ family, is only expressed in the gonads (Cate et al., 1986) and is correlated to ovarian follicular development (Visser et al., 2007). AMH expression is observed in granulosa cells of growing preantral and antral follicles (Rico et al., 2011), and it is described as a premature modulator of follicular growth by controlling premature depletion of the follicular reserve in ovaries (Monniaux et al., 2012; Durlinger et al., 2002). Intrafollicular AMH expression increases until the size of the follicle is $5 \mathrm{~mm}$ in cows (Rico et al., 2011) and $4 \mathrm{~mm}$ in humans (Weenen et al., 2004) and then starts decreasing in larger antral follicles (Monniaux et al., 2008).

Furthermore, the positive association between $\mathrm{AMH}$ and total number of follicles has been described in the ovaries of mice (Durlinger et al., 2002), women (Fanchin et al., 2003), and bovines (B. taurus and B. indicus) (Guerreiro et al., 2014).

In cows, $B$. indicus is superior to $B$. taurus in terms of AFP and plasma AMH concentration (Batista et al., 2014). Considering the strong association between AFP and plasma AMH concentration, analyzing $\mathrm{AMH}$ concentration is a reliable method to predict AFP (Ireland et al., 2011; Rico et al. 2011).

Plasma AMH concentration and ovarian follicular population in heifers has been studied in Nellore and Holstein pubertal heifers (Batista et al., 2014), but not much is known about crossbred prepubertal dairy cattle. Understanding the correlation 
between plasma AMH concentration and AFP in heifers can validate a methodology for premature selection of heifers with high AFP.

Thus, the aim of this study was to evaluate the correlation between serum AMH plasma and AFP in crossbred dairy heifers and cows.

\section{Material and methods}

\section{Animals and Experimental Design}

The study was performed at the State University of Mato Grosso do Sul. Animals from three different herds were used. Girolando breed cows $(3 / 4 B$. taurus $\times 1 / 4$ B indicus), 36-60-months-old $(\mathrm{n}=30)$, and heifers, 12-14-months-old ( $\mathrm{n}=17)$, were used. None of the heifers exhibited corpus luteum or ovarian follicles above $8 \mathrm{~mm}$ at the time of ultrasonography analyses, indicating a high probability of being pre-pubertal. All animals showed a body score condition that ranged from 2.5 to 3.5 (on a scale of 1-5) (Houghton et al., 1990) and were maintained in a grazing system with ad libitum access to water and minerals. They were neither pregnant nor lactating. All procedures were approved by the Committee of Ethic and Animal Use of the State University of Mato Grosso do Sul, Aquidauana, MS (Protocol CEUA-UEMS 021-2013).

\section{Ultrasonographic evaluations}

A single procedure of follicular counting was performed for each experimental animal. Transvaginal ultrasonography was performed using ultrasound equipment attached to a $7.5-\mathrm{MHz}$ micro-convex transducer (Aquila $^{\circledR}$, Pie Medical, Maastricht, The Netherlands). Before each procedure, feces were removed from the rectum and the perianal area was washed using tap water. Follicles of $\geq 3 \mathrm{~mm}$ in diameter in both ovaries were counted to characterize AFP. In order to count the follicles, the operator promoted a slow rotation of about $180^{\circ}$ to make sure all follicles were counted at once. Immediately after counting with the help of a "cineloop" (an instrument of the ultrasound that records images in few seconds), AFP was checked The same individual performed the counting procedure in all animals.

\section{Blood collection and hormonal analysis}

Of the 47 evaluated animals, serum samples from 11 cows and seven heifers were subjected to the $\mathrm{AMH}$ quantification. Blood samples were collected by the venipuncture flow method on the day of AFP counting, were immediately placed in an icebox, and then RT centrifuged at $3000 \mathrm{rpm}$ for $10 \mathrm{~min}$ to allow separation of the serum. After that, samples were frozen at $-20^{\circ} \mathrm{C}$ until further analysis. Plasma $\mathrm{AMH}$ concentration was assessed using a kit for bovine $\mathrm{AMH}$ (ELISA AL-114, Ansh Labs, Webster, TX, USA), and the concentration was expressed as $\mathrm{ng} / \mathrm{mL}$. The interassay coefficient of variation ranged from 0.28 to 3.15 . All assays were performed at the Animal Endocrinology Laboratory of the Paulista State University (UNESP), Araçatuba, SP.

\section{Statistical Analyses}

All data were assessed using the Statistical Analysis System (SAS), version 9.3 and were represented as means \pm SD (standard deviation), except for correlation. Follicular population was analyzed using the PROC MIXED option, and Pearson's correlation was determined using the PROC CORR option of SAS 9.3. The data were assessed according to the number of follicles, and AMH quantification was performed to determine its effect in the animal category. For all analyses, $\mathrm{P} \leq 0.05$ was considered as significant.

\section{Results}

The number of antral ovarian follicles observed through transvaginal ultrasonography was higher in cows $(\mathrm{P}<0.05)$ than that in heifers. AFP ranged from 5 to 70 follicles in cows and from 10 to 31 follicles in heifers. However, plasma AMH concentration did not vary $(P=0.19)$ between the categories (Table 1$)$

A high correlation between AFP and AMH concentration ( $\mathrm{r}=0.87 ; \mathrm{P}=0.0102$ ) was observed in heifers; however, this correlation was not observed in cows $(r=0.48 ; \mathrm{P}=0.1351$; Figure 1$)$.

Table 1. Number of follicles greater than $3 \mathrm{~mm}$ and plasma AMH concentration in Girolando cows and heifers $\underline{(\text { Means } \pm \text { SD) }}$

\begin{tabular}{lccc}
\hline & Cows (n) & Heifers (n) & Value P* \\
\hline Number of follicles & $25,93 \pm 12,6$ & $19,23 \pm 5,34$ & 0,05 \\
AMH $(\mathrm{ng} / \mathrm{mL})$ & $(30)$ & $(17)$ & 0,19 \\
\hline
\end{tabular}

*Significant values at $\mathrm{P} \leq 0.05$. 

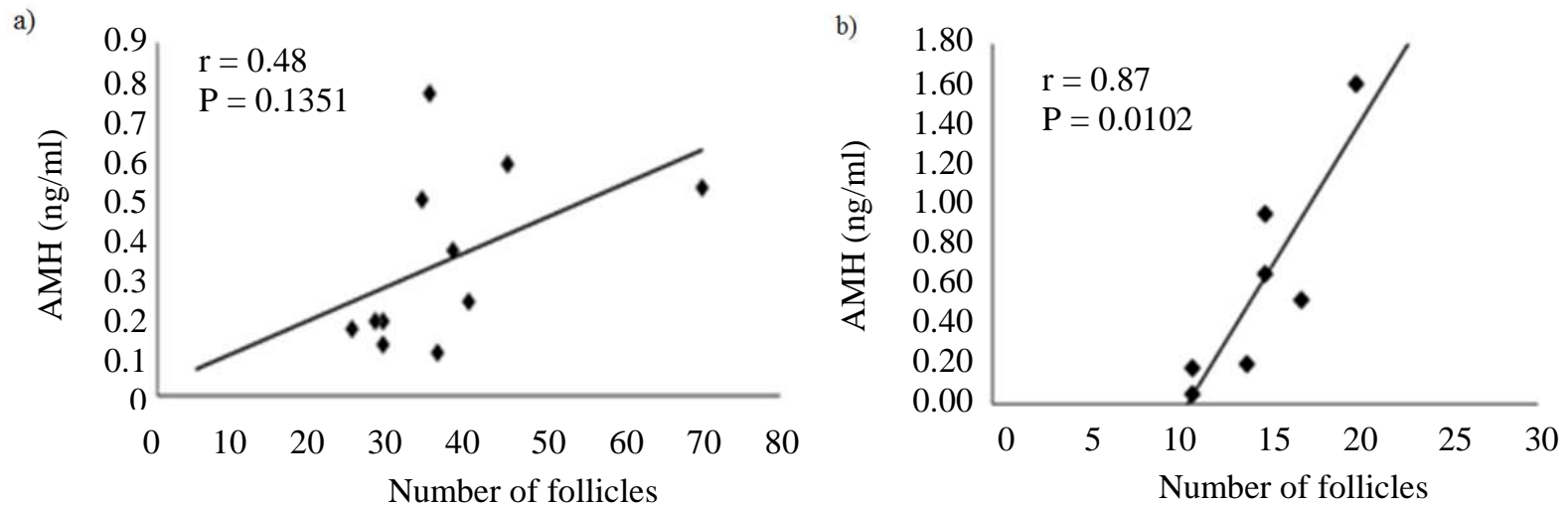

Figure 1. Correlation of plasma AMH concentration and antral follicle ovarian population of cows (A) and Girolando heifers (B).

\section{Discussion}

The present study showed a remarkable difference in AFP between heifers and cows. Nonetheless, no difference was observed in plasma AMH concentration between both categories of Girolando breed.

$\mathrm{AMH}$ is an excellent endocrine marker of small antral follicle, which is the direct target of ovarian stimulatory treatments. Plasma AMH concentration before superovulation varies among animals and is positively correlated to the number of ovulations and transferable embryos produced (Monniaux et al., 2010; Rico et al., 2009).

Animals with higher AFP have an increased probability to produce higher numbers of in vitro embryos (Silva-Santos et al., 2014b), thereby propelling the application of this information as a selection trait. Furthermore, high variability in AFP among individuals (Silva-Santos et al., 2014b) and among distinct bovine breeds has been well-documented (Rodrigues et al., 2015; Oliveira Junior et al., 2015; Batista et al., 2014; Guerreiro et al., 2014; Rico et al., 2011), indicating that AFP is an important trait for animal selection.

In crossbred beef cows and heifers, AFP is correlated to birth weight and age; an increase in AFP is observed until five years of age, after which AFP decreases (Cushman et al., 2009). In consonance with these data, the present study attained higher AFP in cows than that in heifers of the same breed. However, some previous results do not conform to this observation and did not observe any variation in AFP between young and adult Braford heifers (Silva-Santos et al., 2014b). This divergence between breeds may be due to variations within the individuals of different breeds, lineages, or selective pressure applied in a particular herd.

High plasma AMH concentration is positively associated with the total number of follicles in the ovaries of mice (Durlinger et al., 2002) women (Fanchin et al., 2003), and bovines (Batista et al., 2014). Superior AFP (Holstein cows, 25 follicles; Nellore, 47 follicles) and plasma $\mathrm{AMH}$ concentration (Holstein cows, $0.3 \mathrm{ng} / \mathrm{mL}$; Nellore, $0.97 \mathrm{ng} / \mathrm{mL}$ ) have been observed in zebu heifers compared to those in taurine heifers (Batista et al., 2014). Moreover, higher plasma AMH concentration in Nellore cows $(2.3 \mathrm{ng} / \mathrm{mL})$ compared to that in Holstein $(0.4 \mathrm{ng} / \mathrm{mL})$ has been observed (Guerreiro et al., 2014). In the present study, plasma AMH concentration was $0.34 \pm 0.17 \mathrm{ng} / \mathrm{mL}$, which is close to that observed for taurine breed.

It is important to note that the animals used in this assay were crossbreeds ( $3 / 4 \mathrm{~B}$ taurus $\times 1 / 4 \mathrm{~B}$. indicus); thus, it will be necessary to verify whether the trait increases based on the crossing performed.

Several studies in women (Fanchin et al., 2003) and bovines (Guerreiro et al., 2014) demonstrated no variation in plasma AMH concentration across the lifespan, particularly between young and adult individuals.

Increasing reproductive biotechnological methods have been performed in young heifers. Recently, Ovum Pick-Up (OPU) has been performed in Holstein calves (Bayeux et al., 2016). Despite the difficulty in performing ultrasound examinations in young heifers and considering animal welfare, our results stated that a single plasma AMH analysis could help in selecting heifers with higher AFP that would probably better respond to OPU. The cost of $\mathrm{AMH}$ quantification is still the largest limitation of this technique; however, an increased demand could change this situation.

In conclusion, Girolando ( $3 / 4$ Hosltein $\times 1 / 4$ Gir) cows (24-60-months-old) have higher AFP than heifers (12-14-months-old); however, plasma AMH concentration did not differ between the categories. High correlation of AFP and plasma AMH concentration was observed in Girolando heifers. Thus, it is suggested that AMH quantification can predict AFP in Girolando heifers.

\section{Acknowledgements}

The authors would like to thank the staff at Aquidauana Campus -UEMS (Aquidauana-MS) for allowing the use of their animals and facilities during this study. The authors are also grateful to the Animal Endocrinology Laboratory of the Paulista State University (UNESP), Araçatuba, São Paulo for performing AMH assays. This research was supported by CAPES, CNPq and Fundect. 


\section{References}

Baldrighi J, Sa Filho MF, Batista EO, Lopes RN, Visintin JA, Baruselli PS, Assumpcao ME. 2014: Anti-Mullerian hormone concentration and antral ovarian follicle population in Murrah heifers compared to Holstein and Gyr kept under the same management. Reprod Domest Anim, 49:1015-1020.

Baruselli OS, Batista EOS, Vieira LM, Souza AH. 2015. Relationship between follicle population, AMH concentration and fertility in cattle. Anim Reprod, 12:487-497.

Batista EO, Macedo GG, Sala RV, Ortolan MD, Sa Filho MF, Del Valle TA, Jesus EF, Lopes RN, Renno FP, Baruselli PS. 2014. Plasma antimullerian hormone as a predictor of ovarian antral follicular population in Bos indicus (Nelore) and Bos taurus (Holstein) heifers. Reprod Domest Anim, 49:448-452.

Bayeux BM, Carvalho LM, Watanabe YF, Mingoti RD, Oliveira AdS, Chiba MO, Azrak AJ, Castro PMdN, Souza AH, Baruselli PS. 2016. Efeito da categoria (pré-púberes, púberes e prenhes) na produção in vitro de embriões de novilhas da raça holandesa [in portuguese]. In: XXX Reunião Anual da Sociedade Brasileira de Tecnologia de Embriões, 25 a 27 de agosto, 2016, Foz do Iguaçu. Anais... Foz do Iguaçu: Paraná, Brasil, p.256. Abstract.

Borges CRA, Azevedo M, Lima IA, Brasil LHA, Ferreira MA. 2012. Heterogeneous genetic cows of three genetic groups in feedlot system in the state of Pernambuco, Brazil. Acta Sci Anim Sci, 34:91-96.

Cate RL, Mattaliano RJ, Hession C, Tizard R, Farber NM, Cheung A, Ninfa EG, Frey AZ, Gash DJ, Chow EP, Fisher RA, Bertonis JM, Torres G, Wallner BP, Ramachandran KL, Ragin RC, Manganaro TF, Maclaughlin DT, Donahoe PK 1986. Isolation of the Bovine and Human Genes for Mullerian Inhibiting Substance and Expression of the Human-Gene in Animal-Cells. Cell, 45:685-698.

Cushman RA, Allan MF, Kuehn LA, Snelling WM, Cupp AS, Freetly HC. 2009. Evaluation of antral follicle count and ovarian morphology in crossbred beef cows: investigation of influence of stage of the estrous cycle, age, and birth weight. J Anim Sci, 87:1971-1980.

Durlinger AL, Gruijters MJ, Kramer P, Karels B, Ingraham HA, Nachtigal MW, Uilenbroek JT, Grootegoed JA, Themmen AP. 2002. Anti-Mullerian hormone inhibits initiation of primordial follicle growth in the mouse ovary. Endocrinology, 143:1076-1084.

Evans AC, Mossa F, Fair T, Lonergan P, Butler ST, Zielak-Steciwko AE, Smith GW, Jimenez-Krassel F, Folger JK, Ireland JL, Ireland JJ. 2010. Causes and consequences of the variation in the number of ovarian follicles in cattle. Soc Reprod Fertil Suppl, 67:421-429.

Fanchin R, Schonauer LM, Righini C, Guibourdenche J, Frydman R, Taieb J. 2003. Serum anti-Mullerian hormone is more strongly related to ovarian follicular status than serum inhibin B, estradiol, FSH and LH on day 3. Hum Reprod, 18:323-327.

Ghanem N, Jin JI, Kim SS, Choi BH, Lee KL, Ha AN, Song SH, Kong IK. 2016. The Anti-Mullerian Hormone Profile is Linked with the In Vitro Embryo
Production Capacity and Embryo Viability after Transfer but Cannot Predict Pregnancy Outcome. Reprod Domest Anim, 51:301-310.

Gobikrushanth M, Dutra PA, Bruinje TC, Colazo MG, Butler ST, Ambrose DJ. 2017. Repeatability of antral follicle counts and anti-Mullerian hormone and their associations determined at an unknown stage of follicular growth and an expected day of follicular wave emergence in dairy cows. Theriogenology, 92:90-94.

Guerreiro BM, Batista EO, Vieira LM, Sa Filho MF, Rodrigues CA, Castro Netto A, Silveira CR, Bayeux BM, Dias EA, Monteiro FM, Accorsi M, Lopes RN, Baruselli PS. 2014. Plasma anti-mullerian hormone: an endocrine marker for in vitro embryo production from Bos taurus and Bos indicus donors. Domest Anim Eendocrinol, 49:96-104.

Houghton P, Lemenager R, Hendrix K, Moss G, Stewart T. 1990. Effects of body composition, pre-and postpartum energy intake and stage of production of energy utilization by beef cows. J Anim Sci, 68:14471456.

Ireland JJ, Smith GW, Scheetz D, Jimenez-Krassel F, Folger JK, Ireland JL, Mossa F, Lonergan P, Evans AC. 2011. Does size matter in females? An overview of the impact of the high variation in the ovarian reserve on ovarian function and fertility, utility of anti-Mullerian hormone as a diagnostic marker for fertility and causes of variation in the ovarian reserve in cattle. Reprod Fertili Dev, 23:1-14.

Monniaux D, Clemente N, Touze JL, Belville C, Rico C, Bontoux M, Picard JY, Fabre S. 2008. Intrafollicular steroids and anti-mullerian hormone during normal and cystic ovarian follicular development in the cow. Biol Reprod, 79:387-396.

Monniaux D, Drouilhet L, Rico C, Estienne A, Jarrier P, Touze J. L, Sapa J, Phocas F, Dupont J, Dalbies-Tran R, Fabre S. 2012. Regulation of antiMullerian hormone production in domestic animals. Reprod Fertil Dev, 25:1-16.

Monniaux D, Rico C, Larroque H, Dalbies-Tran R, Medigue C, Clement F, Fabre S. 2010. Anti-Mullerian hormone, an endocrine predictor of the response to ovarian stimulation in the bovine species. Gynecol Obstet Fertil, 38:465-470.

Morotti F, Barreiros TRR, Machado FZ, Gonzylez SM, Marinho LSR, Seneda MM. 2015. Is the number of antral follicles an interesting selection criterium for fertility in cattle? Anim Reprod, 12:479-486.

Oliveira Junior JS, Cardoso CJT, Silva WAL, Kischel H, Souza MB, Andrade ER, Nogueira E, Silva-Santos KC, Seneda MM, de Andrade MeloSterza F. 2015. Antral follicles population in heifers and cows of Nelore and Girolando breeds. Semina: Ciênc Agrár, 36:3741-3750.

Rico C, Fabre S, Medigue C, di Clemente N, Clement F, Bontoux M, Touze JL, Dupont M, Briant E, Remy B, Beckers JF, Monniaux D. 2009. Antimullerian hormone is an endocrine marker of ovarian gonadotropin-responsive follicles and can help to predict superovulatory responses in the cow. Biol Reprod, 80:50-59.

Rico C, Medigue C, Fabre S, Jarrier P, Bontoux M, 
Clement F, Monniaux D. 2011. Regulation of antiMullerian hormone production in the cow: a multiscale study at endocrine, ovarian, follicular, and granulosa cell levels. Biol Reprod, 84:560-571.

Rodrigues AS, Oliveira SN, Loiola MVG, Ferraz PA, Chalhoub $M$, Bittencourt RF, Araujo EAB, Bittencourt TCBdS, Ribeiro Filho AL. 2015. Antral follicle count in Nelore females subjected to fixed-time artificial insemination. Ciênc Rural, 45:711-717.

Silva-Santos KC, Santos GM, Koetz Junior C, Morotti F, Siloto LS, Marcantonio TN, Urbano MR, Oliveira RL, Lima DC, Seneda MM. 2014a: Antral follicle populations and embryo production-in vitro and in vivo-of Bos indicus-taurus donors from weaning to yearling ages. Reprod Domest Anim, 49:228-232.

Silva-Santos KC, Siloto LS, Santos GM, Morotti F, Marcantonio TN, Seneda MM. 2014b. Comparison of antral and preantral ovarian follicle populations between
Bos indicus and Bos indicus-taurus cows with high or low antral follicles counts. Reprod Domest Anim, 49:48-51.

Silva MVGB, Martins MF, Paiva LC, Cembranelli MAR, Arbex WA, Santos KCL. 2014. Programa de Melhoramento Genético da Raça Girolando Avaliação Genética de Vacas [in portuguesse]. Documentos 173 Embrapa Gado de Leite, Juiz de Fora, MG.

Visser JA, Durlinger AL, Peters IJ, van den Heuvel ER, Rose UM, Kramer P, de Jong FH, Themmen AP. 2007. Increased oocyte degeneration and follicular atresia during the estrous cycle in anti-Mullerian hormone null mice. Endocrinology, 148:2301-2308.

Weenen C, Laven JS, Von Bergh AR, Cranfield M, Groome NP, Visser JA, Kramer P, Fauser BC, Themmen AP. 2004. Anti-Mullerian hormone expression pattern in the human ovary: potential implications for initial and cyclic follicle recruitment. Mol Hum Reprod, 10:77-83. 